\title{
Penghapusan Pidana Bagi Pejabat NegARA PENERIMA GRATIFIKASI
}

\author{
Nur Laeli Fauziah $\mid$ Jl. Kendal Kemlagi Karanggeneng \\ nurlaeli@gmail.com $\quad$ Lamongan
}

\begin{abstract}
The abolition of the criminal sanction to the state official as a gratification receiver who report himself to the Corruption Eradication Commission (KPK) on Article 12 of Law No. 31/1999 C jo. Law No. 20/2001. These two laws indicate the weaknesses in the material of the criminal law, namely the elimination of against the material law in the form of administrative procedure when reporting on the Corruption Eradication Commission (KPK). In Islamic jurisprudence, there is a method called sadd al-dzar ah. It is a preventive measure in order not to happen a negative impact. Islamic law does not only regulate human behavior that has been done, but also what has not been done. The similarity between positive law and Islamic criminal law is that both are equally prohibiting the gratification of the state official. While the difference lies on the punishment and the implication which is given to the recipient of gratification at the time of reporting or not reporting it to the Commission. Keywords: Elimination of the criminal sanction, state official, gratification, Islamic criminal law.
\end{abstract}

Abstrak: Penghapusan Pidana bagi pejabat negara penerima gratifikasi yang melaporkan diri kepada Komisi Pemberantasan Tindak Pidana Korupsi (KPK) pada Pasal 12 C UU 31/1999 jo. UU 20/2001 mengindikasikan adanya kelemahan dalam hukum pidana materiil, yaitu penghapusan sifat melawan hukum materiil berwujud prosedur administrasi ketika melapor di Komisi Pemberantasan Tindak Pidana Korupsi (KPK). Dalam fikih terdapat metode yang dinamakan sadd al$d z a r$ ah, yaitu upaya preventif agar tak terjadi sesuatu yang menimbulkan dampak negatif. Hukum Islam tidak hanya mengatur perilaku manusia yang sudah dilakukan, tetapi juga yang belum dilakukan.Persamaan hukum positif dan fikih jin yah pada gratifikasi kepada pejabat negara terletak pada hukumnya yakni kedua sumber hukum tersebut sama-sama melarang tindakan gratifikasi. Sedangkan perbedaannya terletak pada hukuman dan implikasi yang diberikan terhadap penerima gratifikasi pada waktu melaporkan maupun tidak melaporkannya kepada KPK.

Kata Kunci: Penghapusan pidana, pejabat negara, gratifikasi, fikih jin yah 


\section{Pendahuluan}

Penanggulangan korupsi diperlukan aturan hukum dan penegakannya yang memberi kepastian hukum kepada setiap orang, agar keadilan dan kesejahteraan masyarakat dapat tercapai. ${ }^{1}$ Permasalahan korupsi bukanlah masalah baru di Indonesia, karena sejak era tahun 1950-an telah banyak terjadi. Berbagai kalangan menilai bahwa korupsi telah menjadi bagian dari kehidupan, menjadi suatu sistem dan menyatu dengan penyelenggaraan pemerintah negara. Pelaksanaan UndangUndang No. 3 Tahun 1971 tentang Pemberantasan Tindak Pidana Korupsi banyak menemui kegagalan penanggulangan korupsi di era tersebut. Salah satu penyebabnya adalah penegakan oleh berbagai institusi yang dibentuk untuk pemberantasan korupsi tidak menjalankan fungsinya dengan efektif, perangkat hukum yang lemah, ditambah dengan aparat penegak hukum yang tidak sungguh-sungguh menyadari akibat serius dari tindakan korupsi. ${ }^{2}$

Sebagai bagian dari upaya pemberantasan korupsi, gratifikasi menjadi perhatian khusus, karena merupakan ketentuan yang baru dalam perundang-undangan dan perlu sosialisasi yang lebih optimal. Undang-Undang Nomor 31 tahun 1999 tentang Pemberantasan Tindak Pidana Korupsi, sesuai amanat reformasi yang ingin menuntaskan praktik busuk korupsi, dinilai belum memadai. Untuk itulah melalui Ketetapan MPR RI Tahun 2001 ditambahkan delik baru mengenai pemberian atau yang dalam Undang-Undang Nomor 20 tahun 2001 dipakai istilah gratifikasi. Masuknya item gratifikasi dalam khasanah hukum (pidana) terbilang baru. ${ }^{3}$

Pengertian tentang gratifikasi sebagaimana dijelaskan dalam Pasal 12 B Undang-Undang No. 31 tahun 1999 jo. Undang-Undang Nomor 20 Tahun 2001 tentang Pemberantasan Tindak Pidana Korupsi adalah setiap bentuk pemberian kepada pegawai negeri atau penyelenggara negara apabila berhubungan dengan jabatannya dan yang berlawanan dengan kewajiban atau tugasnya.

Pemberian kepada pejabat publik itu akibat dari kewenangan yang dimilikinya, bukan disebabkan adanya relasi atau intimitas yang sifatnya

\footnotetext{
${ }^{1}$ Nurdjana, Korupsi dalam Praktik Bisnis: Pemberdayaan Penegakan Hukum Program Aksi dan Strategi Penanggulangan Masalah Korupsi (Jakarta: Gramedia Utama, 2005), 20.

${ }^{2}$ Chaerudin, et al, Strategi Pencegahan dan Penegakan Hukum Tindak Pidana Korupsi (Bandung: Refika Aditama, 2008), 1.

${ }^{3}$ Ibid., 25.
} 
personal semata, tanpa embel-embel statusnya sebagai pejabat publik. Pemberian dimaksud di atas adalah pemberian dalam arti luas meliputi: pemberian uang, barang, rabat atau diskon, komisi, pinjaman tanpa bunga, tiket perjalanan, fasilitas penginapan, perjalanan wisata, pengobatan cuma-cuma, dan fasilitas lainnya. ${ }^{4}$ Menurut Pasal $12 \mathrm{~B}$ Undang-Undang No. 31 tahun 1999 jo. Undang-Undang No 20 Tahun 2001 dikatakan setiap gratifikasi kepada pegawai negeri atau penyelenggara negara dianggap pemberian suap, apabila berhubungan dengan jabatannya dan yang berlawanan dengan kewajiban atau tugasnya. Sebagai contoh, ketika Gubernur DKI Jakarta Joko Widodo menerima gitar dari personel band metallica saat melihat konsernya, Joko Widodo segera melaporkan pemberian tersebut kepada KPK untuk diperiksa apakah pemberian tersebut termasuk gratifikasi atau tidak.

Berdasarkan pada Pasal 12 C Undang-Undang No 20 Tahun 2001 gratifikasi tidak dianggap sebagai suap, jika penerima melaporkan gratifikasi yang diterimanya kepada Komisi Pemberantasan Tindak Pidana Korupsi (KPK) paling lambat 30 (tiga puluh) hari terhitung sejak gratifikasi diterima. Dengan demikian, berdasarkan Pasal 12 C UndangUndang No. 20 Tahun 2001 jo. Undang-Undang No. 31 tahun 1999 gratifikasi tidak dianggap sebagai suap jika penerima melaporkan gratifikasinya, hal ini berarti juga tidak dapat dipidananya penerima gratifikasi tersebut. Penerima baru dapat dipidana apabila tidak melapor kepada KPK, perumusan Pasal $12 \mathrm{C}$ ini terkesan sebagai alasan penghapus pidana. ${ }^{5}$

Terdapat unsur kesenjangan dalam pasal tersebut, karena seolahseolah sifat melawan hukumnya perbuatan atau sifat patut dipidananya si penerima digantungkan pada ada atau tidaknya laporan. Persyaratan administratif tidak dipidananya tindak pidana korupsi ini dirasakan janggal, sekiranya korupsi dipandang sebagai perbuatan yang pada hakikatnya sangat tercela (intrinsically wrong). ${ }^{6}$

Pemberian hadiah atau gratifikasi kepada seseorang terkait kapasitasnya sebagai pejabat atau penyelenggara negara bukanlah sesuatu yang baru. Tradisi Islam sendiri mewariskan kepada kita jejak sejarah mengenai hal tersebut. Salah satu bentuk gratifikasi yang diartikan

\footnotetext{
${ }^{4}$ Republik Indonesia, Kumpulan Undang-Undang Tindak Pidana Korupsi (Bandung: Citra Umbara, 2008), 31.

${ }^{5}$ Barda Nawawi Arief, Kapita Selekta Pidana (Bandung: Citra Aditya Bakti, 2003), 112.

${ }^{6}$ Ibid., 113.
} 
sebagai suap pada zaman Nabi Muhammad saw.adalah kasus pemberian hadiah kepada Ibn al-Lutbiyyah, seorang pejabat yang diangkat oleh Rasulullah sebagai penarik zakat dan shadaqah di Distrik Bani Sulaim. ${ }^{7}$

"Dari Abu Humaid as-Sa'idi, "Rasulullah mempekerjakan seorang dari suku Azd bernama Ibn Lutbiyah dengan tugas mengumpulkan zakat. Setelah selesai berkeliling dan tiba di Madinah, dia berkata kepada Nabi, 'Ini untuk anda sedangkan yang ini adalah hadiah untukku." Mendengar laporan semacam itu, Nabi saw bersabda: "Coba dia hanya duduk manis di rumah ayah atau ibunya. Coba dia lihat apakah dia mendapatkan kiriman hadiah ataukah tidak. Demi Allah yang jiwaku ada di tangan-Nya setiap orang yang menerima hadiah semacam ini akan memikulnya pada hari kiamat nanti, boleh jadi hadiah yang dipikul itu berupa onta yang bersuara sebagaimana suara onta, sapi atau pun kambing yang bersuara dengan suara khasnya masing masing." Kemudian Nabi mengangkat tangannya hingga kami melihat putihnya ketiak beliau. Beliau lantas berkata sebanyak tiga kali, "Ya Allah bukankah aku telah menyampaikan. Ya Allah bukankah aku telah menyampaikan".

Menyalahgunakan wewenang dalam rangka memperoleh sesuatu yang diinginkan dikenal sekarang dengan term korupsi. Dengan demikian, terminologi korupsi yang biasa disebut-sebut sekarang sama dalam bahasa Islam adalah al-ghul l yang memiliki arti berkhianat dalam pembagian harta rampasan perang atau dalam harta-harta lain. Dalam hal ini gratifikasi atau suap berbeda dengan korupsi, kata suap dalam terminologi bahasa disebut al-rishwah. Memang al-rishwah termasuk alghul I, tetapi tidak semua al-ghul I termasuk al-rishwah. Al-ghul I lebih luas dari al-rishwah. Al-ghul 1 merupakan perbuatan yang sangat jahat. Perbuatan itu tidak hanya merugikan satu atau dua orang saja, tetapi merugikan seluruh masyarakat dari segala aspek karena harta yang diambil adalah harta masyarakat yang adalah di negara (kas) yang digunakan untuk kepentingan masyarakat.'

Perolehan yang pada prinsipnya dibolehkan, seperti infak, sedekah, pemberian, dan hadiah, dapat berubah status hukumnya menjadi haram jika yang menerima itu adalah para pejabat pemerintah

\footnotetext{
${ }^{7}$ Ervyn Kaffah, Moh. Asyiq Amrulloh, Fiqh Korupsi: Amanah Vs Kekuasaan (NTB: Solidaritas Masyarakat Transparansi, 2003), 285.

${ }^{8}$ Ibid., 287.

${ }^{9}$ Ibid., 277.
} 
atau penyelenggara negara, karena pemberian tersebut dapat menjadi suap (al-rishwah). Hal ini diberlakukan dengan pertimbangan kekhawatiran rusaknya mental pejabat dan pudarnya objektivitas penyelenggara negara dalam melakukan tugas atau menangani suatu perkara. Dengan adanya larangan pemberian segala macam hadiah kepada pejabat, lantas bagaimanakah pandangan hukum pidana Islam terhadap adanya gratifikasi dan penghapusan pidana bagi pegawai negeri atau penyelenggara negara penerima gratifikasi yang melaporkan gratifikasinya kepada KPK?

\section{Penghapusan Pidana bagi Pejabat Negara Penerima Gratifikasi}

Dalam penjelasan pasal 12 B UU No. 20 Tahun 2001, maka disebutkan objek gratifikasi adalah: pemberian uang, barang, rabat (discount), komisi, pinjaman tanpa bunga, tiket perjalanan, fasilitas penginapan, perjalanan wisata, pengobatan cuma-cuma, dan fasilitas lainnya. Gratifikasi tersebut, baik yang diterima di dalam maupun di luar negeri dan yang dilakukan dengan menggunakan sarana elektronik atau tanpa sarana elektronik. ${ }^{10}$ Selain itu terdapat juga kasus-kasus yang dapat digolongkan sebagai gratifikasi yaitu:

1. Pembiayaan kunjungan kerja lembaga legislatif karena hal ini dapat mempengaruhi legislasi dan implementasinya oleh eksekutif.

2. Cinderamata bagi guru (PNS) setelah pembagian rapor/ kelulusan.

3. Pungutan liar di jalan raya dan tidak disertai tanda bukti dengan tujuan sumbangan tidak jelas, oknum yang terlibat bisa jadi dari petugas kepolisian (polisi lalu lintas), retribusi (dinas pendapatan daerah), LLAJR dan masyarakat (preman). Apabila kasus ini terjadi KPK menyarankan pelaporan yang dipublikasikan ke media massa dan penindakan tegas pada pelaku.

4. Uang restribusi masuk pelabuhan tanpa tiket yang dilakukan oleh Instansi Pelabuhan, Dinas Perhubungan, dan Dinas Pendapatan Daerah. Parsel ponsel canggih keluaran terbaru dari pengusaha ke pejabat.

5. Perjalanan wisata bagi Bupati menjelang akhir jabatan.

Pasal $12 \mathrm{C}$ ayat (1), apabila penerima melaporkan gratifikasi yang diterimanya kepada Komisi Pemberantasan Tindak Pidana

\footnotetext{
10 Adami Chazawi, Hukum Pidana Materil dan Formil Korupsi di Indonesia (Malang: Bayumedia Publishing, 2005), 259-260.
} 
Korupsi, maka gratifikasi itu tidak dianggap sebagai pemberian suap. Berarti juga tidak dapat dipidana. Baru dapat dipidana apabila si penerima tidak lapor. Perumusan Pasal $12 \mathrm{C}$ ayat (1) ini terkesan sebagai alasan penghapus pidana. ${ }^{11}$ Pasal $12 \mathrm{C}$ Undang-Undang No. 20 tahun 2001 tentang Pemberantasan Tindak Pidana Korupsi menyebutkan: ${ }^{12}$

(1) Ketentuan sebagaimana dimaksud dalam Pasal 12B ayat (1) tidak berlaku jika penerima melaporkan gratifikasi yang diterimanya kepada Komisi Pemberantasan Tindak Pidana Korupsi.

(2) Penyampaian laporan sebagaimana dimaksud dalam ayat (1) wajib dilakukan oleh penerima gratifikasi paling lambat 30 (tiga puluh) hari kerja terhitung sejak tanggal gratifikasi tersebut diterima.

(3) Komisi Pemberantasan Tindak Pidana Korupsi dalam waktu paling lambat 30 (tiga puluh) hari kerja sejak tanggal menerima laporan, wajib menetapkan gratifikasi dapat menjadi milik penerima atau milik negara.

(4) Ketentuan mengenai tata cara penyampaian laporan sebagaimana dimaksud dalam ayat (2) dan penentuan status gratifikasi sebagaimana dimaksud dalam ayat (3) diatur dalam UndangUndang tentang Komisi Pemberantasan Tindak Pidana Korupsi. ${ }^{13}$

Dilihat secara substansial, hal ini dirasakan janggal, karena seolaholah sifat melawan hukumnya perbuatan atau sifat patut dipidananya si penerima ditergantungkan pada ada/tidaknya laporan (yang bersifat administratif prosedural). Persyaratan administratif prosedural untuk tidak dipidananya tindak pidana korupsi ini dirasakan janggal, sekiranya korupsi dipandang sebagai perbuatan yang "pada hakikatnya" sangat tercela (merupakan "rechtdelict", "mala per se", atau "intrinsically wrong"). ${ }^{14}$

Memperhatikan perumusan Pasal 12 B dan Pasal 12 C ayat (1), maka untuk dapat dipidananya 19 si penerima gratifikasi harus dipenuhi unsur-unsur sebagai berikut: ${ }^{15}$

\footnotetext{
${ }^{11}$ Barda Nawawi Arief, Kapita Selekta Hukum, 112.

${ }^{12}$ Evi Hartanti, Tindak Pidana Korupsi (Jakarta: Sinar Grafika, 2005), 8.

13 Ibid., 19.

${ }^{14}$ Barda Nawawi Arief, Kapita Selekta Hukum, 113.

15 Andi Hamzah, Pemberantasan Korupsi melalui Hukum Pidana Nasional dan Internasional, (Jakarta: PT Raja Grafindo Persada, 2005), 4.
} 
1. Penerima harus berkualifikasi sebagai "pegawai negeri" atau sebagai "penyelenggara negara".

2. Menerima "gratifikasi" dari seseorang yang merupakan "pemberian suap" menurut Pasal 12 B ayat (1). menurut Pasal 12 B ayat (1), yaitu apabila pemberian itu "berhubungan dengan jabatannya dan berlawanan dengan kewajibannya”.

3. Penerima tidak melaporkan melaporkan gratifikasi yang diterimanya kepada Komisi Pemberantasan Tindak Korupsi.

Dalam konteks ini, bahwa jumlah/nilai "gratifikasi" tidak menjadi unsur substantif, karena dalam Pasal 12 B ayat (1) hanya dirumuskan sebagai unsur prosedural. Adanya unsur ke-3 di atas, yaitu tidak melaporkan ke Komisi Pemberantasan Tindak Pidana Korupsi yang diatur dalam Pasal 12 C ayat (1), mirip dengan Pasal 1 sub 1 e UndangUndang Nomor 3 tahun 1971 yang tidak lagi dimasukkan sebagai Tindak Pidana Korupsi dalam Undang- Undang Nomor 31 tahun 1999. Jadi, Undang-Undang Nomor 20 tahun 2001 ini terkesan "menghidupkan kembali" Pasal 1 sub 1 e Undang-Undang Nomor 3 tahun 1971.21 Isi dari Pasal tersebut adalah "Barang siapa tanpa alasan yang wajar, dalam waktu yang sesingkat-singkatnya setelah menerima pemberian atau janji yang diberikan kepadanya, seperti yang tersebut dalam Pasal-pasal 418, 419 dan 420 KUHP tidak melaporkan pemberian atau janji tersebut kepada yang berwajib". ${ }^{16}$

Secara yuridis, bahwa Pasal $12 \mathrm{C}$ ayat (1) merupakan perbuatan yang tidak dianggap sebagai suap jika si penerima gratifikasi melaporkan gratifikasi yang diterimanya kepada KPK, (2) Si penerima gratifikasi melaporkan ke KPK paling lambat 30 (tiga puluh) hari terhitung sejak gratifikasi diterima, (3) KPK dalam waktu 30 (tiga puluh) hari menentukan status gratifikasi dapat menjadi milik penerima atau milik negara. Gratifikasi menjadi milik negara jika gratifikasi tersebut diduga sebagai suap. Secara a contrario gratifikasi menjadi milik penerima jika tidak terkait dengan penyuapan. ${ }^{17}$

Penyelenggara negara yang dimaksud berdasarkan Pasal 2 Undang-Undang Nomor 28 Tahun 1999 tentang Penyelenggara Negara yang Bersih dan Bebas dari Korupsi, Kolusi, dan Nepotisme, meliputi Pejabat Negara pada Lembaga Tertinggi Negara, Pejabat Negara pada

\footnotetext{
${ }^{16}$ Ibid., 5.

${ }^{17}$ Doni Muhardiansyah, dkk., Buku Saku Memahami, 11.
} 
Lembaga Tinggi Negara, Menteri, Gubernur, Hakim, Pejabat negara yang lain sesuai dengan ketentuan peraturan perundangundangan yang berlaku (Duta Besar, Wakil Gubenur, Bupati/Walikota) dan Pejabat lain yang memiliki fungsi strategis dalam kaitannya dengan penyelenggaraan negara sesuai dengan ketentuan peraturan perundangundangan yang berlaku: Komisaris, Direksi, Pejabat Struktural pada BUMN dan BUMD; Pimpinan BI dan Pimpinan Badan Penyehatan Perbankan Nasional; Pimpinan Perguruan Tinggi Negeri; Pejabat Eselon Satu dan pejabat lain yang disamakan pada lingkungan sipil, militer, dan kepolisian negara RI; Jaksa; Penyidik; Panitera Pengadilan dan Pimpinan dan Bendahara Proyek. ${ }^{18}$

Gratifikasi dianggap sebagai suap jika si penerima gratifikasi pegawai negeri atau penyelenggara negara yang mempunyai jabatan dan si penerima (pejabat) melakukan suatu perbuatan yang berlawanan dengan kewajiban atau tugasnya. Yang perlu mendapatkan perhatian di sini bahwa pejabat tidak selalu pegawai negeri dan pegawai negeri itu tidak selalu pejabat. ${ }^{19}$

Jabatan akan melahirkan suatu kewenangan atau adanya kewenangan karena memangku suatu jabatan tertentu. Tidak ada kewenangan tanpa suatu jabatan. Atas dasar pemahaman terhadap konsep tersebut, tidak pada tempatnya semua pegawai negeri dilarang menerima segala bentuk gratifikasi (pemberian hadiah). Selain itu, perlu diperhatikan siapa pemberi gratifikasi. Sebab, jika pemberian tersebut tidak mempunyai suatu maksud agar si penerima gratifikasi melakukan perbuatan melawan hukum (berlawanan dengan kewajiban atau tugasnya), tentu berdasar logika, hukum pemberian gratifikasi tersebut sah-sah saja. Atas dasar itu, tidak setiap pemberian gratifikasi harus dianggap sebagai suap, tetapi harus dilihat siapa yang memberi dan dilihat pula apakah si penerima mempunyai suatu jabatan tertentu. ${ }^{20}$

Jika pemberian itu tidak terkait dengan suatu jabatan, tentu dapat dinyatakan tidak terjadi suap. Gratifikasi sebagai suap jika pemberian gratifikasi merupakan condition sine quanon atas perbuatan pejabat yang berlawanan dengan kewajiban atau tugasnya. Kesesuaian kehendak antara si pemberi dan si penerima gratifikasi harus diperhatikan. Jika

\footnotetext{
${ }^{18}$ Andi Hamzah, Pemberantasan Korupsi melalui Hukum Pidana Nasional, 23-26.

${ }^{19}$ Ibid., 30-35.

${ }^{20}$ Chaerudin, et.al, Strategi Pencegahan Tindak Pidana Korupsi (Bandung: PT. Refika Aditama, 2008), 5 .
} 
tidak ada kesesuaian kehendak antara si pemberi dan si penerima gratifikasi atau tidak ada condition sine quanon antara penerimaan gratifikasi dan perbuatan pejabat yang melawan hukum, tentu tidak dapat dinyatakan terjadi delik suap.

Ilustrasi lain sebagai berikut: Seorang rekanan memenangkan tender tanpa pejabat melakukan perbuatan yang berlawanan dengan kewajiban atau tugasnya. Dengan kata lain, secara normatif memang rekanan itulah pemenangnya, selanjutnya rekanan menyisihkan sebagian keuntungan untuk memberikan hadiah kepada pejabat yang bersangkutan. Pertanyaannya, apakah gratifikasi tersebut sebagai suap? Jawabnya tidak karena rekanan tersebut ditunjuk sebagai pemenang tidak karena suap. ${ }^{21}$

Hal itu berbeda jika secara normatif rekanan tersebut tidak sebagai pemenang. Tapi karena pejabat tersebut telah menerima gratifikasi, rekanan tersebut dimenangkan. Hal inilah yang dapat diklasifikasikan sebagai suap, walaupun pemberian itu dilakukan setelah ditunjuk sebagai pemenang. Desakan untuk menciptakan good governance di birokrasi merupakan tuntutan universal yang tidak bisa ditawar-tawar lagi. Kajian kriminologi menempatkan korupsi secara umum sebagai white collar criminal atau kejahatan kerah putih. Hal ini dikarenakan salah satu pihak yang terlibat atau keduanya berhubungan dengan pekerjaan atau profesinya. Demikian juga dengan tindak pidana Gratifikasi sebagaimana yang ada diatur dalam Pasal 12B UU No. 20 Tahun 2001 tentang Pemberantasan Tindak Pidana Korupsi merupakan salah satu kejahatan yang tergolong sebagai white collar Crime, mengingat kejahatan ini berkembang dikalangan birokrat, yaitu para pegawai negeri dan penyelenggara negara. ${ }^{22}$

Sesuai dengan karakteristik white collar crime, yang memang susah dilacak karena biasanya pelaku adalah orang yang memiliki status sosial tinggi (pejabat), memiliki kepandaian, berkaitan dengan pekerjaannya, yang dengannya memungkinkan pelaku bisa menyembunyikan bukti. Selain itu kerugian yang diakibatkan oleh perilaku korupsi biasanya tidak dengan mudah dan cepat dirasakan oleh

\footnotetext{
${ }^{21}$ Ibid., 8.

${ }^{22}$ Komisi Pemberantasan Korupsi Republik Indonesia, Mengenali dan Memberantas Korupsi (Jakarta: KPK, 2010), 12.
} 
korban. Bandingkan dengan pencurian, perampokan atau pembunuhan. ${ }^{23}$

\section{Penghapusan Pidana dalam Fikih Jin yah}

Objektivikasi hukum Islam dapat ditemukan basis teoretisnya pada teori maslahat. Dalam menghadapi masalah baru yang timbul di tengah kehidupan masyarakat, aplikasi teori maslahat merupakan metode ijtihad yang paling tepat; dan ini telah dipraktikkan dalam sekian banyak ijtihad para Sahabat Nabi, ulama al-t bi' n dan para Imam mazhab. Agenda pembaharuan hukum Islam harus mereposisi aplikasi teori maslahat sebagai formula utama. Yudian Wahyudi menilai bahwa aplikasi teori maslahat sebenarnya merupakan metode yang luar biasa untuk mengembangkan nilai dan ruh hukum Islam ke dalam berbagai masalah. Pengembangan teori ini secara tajam dan bertanggung jawab merupakan kebutuhan yang tidak bisa ditunda-tunda lagi agar umat Islam tidak menjadi umat yang berwawasan sempit dan kerdil. ${ }^{24}$

Tindakan secara letterlejk lebih disesuaikan dengan terjemahan dari istilah feit. "Tindak" pada dasarnya merujuk pada hal kelakuan manusia secara positif (bansden) semata, dan tidak termasuk kelakuan manusia yang bersifat pasif atau negatif (nalaten). ${ }^{25}$ Dan menurutnya, pengertian sebenarnya dalam istilah feit adalah mencakup dua kategori perbuatan, baik perbuatan tersebut aktif maupun pasif, pembagian tindakan hukum ini sesuai dengan pendapat Ahmad Hanafi. Perbuatan aktif artinya suatu bentuk perbuatan yang untuk mewujudkannya diperlukan atau disyaratkan adanya suatu gerakan atau gerakan-gerakan dari tubuh manusia. Sementara itu, perbuatan pasif adalah suatu bentuk tindakan dengan tidak melakukan suatu perbuatan fisik apapun, yang oleh karenanya seseorang tersebut telah mengabaikan kewajiban hukumnya, misalnya tidak menolong, atau perbuatan membiarkan. ${ }^{26}$

Suharto menjelaskan bahwa suatu perbuatan yang melanggar aturan hukum dapat dipidana apabila sudah bisa dinyatakan salah. Apa yang diartikan salah adalah suatu pengertian psikologis yang berarti

\footnotetext{
${ }^{23}$ Chaerudin, et.al, Strategi Pencegahan Tindak Pidana, 10.

${ }^{24}$ Asmawi, Relevansi Teori Maslahat dengan UU Pemberantasan Korupsi (Jakarta : Pustaka Dunia, 2009), 16.

${ }^{25}$ Marsum, Fiqih Jinayat (Hukum Pidana Islam)(Yogyakarta: BAG. Penerbit FH UII, 1991), 2.

${ }^{26}$ Adami Khazawi, Pelajaran Pidana; Stelsel Pidana, Tindak Pidana, Teori-Teori Pemidanaan dan Batasan Berlakunya Hukuman Pidana (Jakarta: PT. Raja Grafindo Persada, 2002), 70.
} 
adanya hubungan batin orang yang melakukan perbuatan dengan perbuatan yang dilakukan sehingga terjadi perbuatan yang disengaja atau alpa. ${ }^{27}$

Sementara itu, terkait dengan tindakan/perbuatan dan pelaku hukum, sebagai syarat suatu peristiwa dapat dikatakan sebagai peristiwa hukum, jika memenuhi ketiga syarat dibawah ini: Harus ada suatu perbuatan manusia yang dikerjakan secara sadar, perbuatan itu harussesuai dengan apa yang dilukiskan di dalam ketentuan hukum, harus terbukti adanya "dosa" (horisontal) pada orang yang berbuat, yaitu orangnya harus dapat dipertanggungjawabkan. Dalam artian, sebagai subyek hukum (pelaku) sudah dapat dinyatakan sebagai subyek yang cakap hukum, sedangkan dosa horisontal ini dalam istilah sosiologi biasa disebut dengan perilaku menyimpang (dari kebiasaan/norma), perbuatan itu harus berlawanan dengan hukum, terhadap perbuatan itu harus tersedia ancaman hukumannya dalam undang-undang. ${ }^{28}$

Dengan demikian, dapat dikatakan bahwa kata "tindakan" ataupun "perbuatan" dalam diskursus hukum banyak digunakan untuk peristiwa yang terjadi pasca konvensi atau positivisasi hukum, lebih jelasnya, sebelum sebuah pekerjaan dipositivisasikan dalam bentuk hukum materiil verbal sebagaimana terkodifikasikan dalam peraturan perundangan, tindakan tersebut belum dapat dikategorikan sebagai tindakan atau perbuatan hukum, baik perbuatan itu bersifat positif maupun negatif. Dan makna tindakan ini kemudian mengalami pergeserannya yang cenderung positivistik.

Dalam hukum pidana Islam (fikih jin yah), tindak pidana (jar mah/delik) jika dilihat dari berat ringannya hukuman dibagi menjadi tiga macam : 1) tindak pidana yang sanksinya dominan ditentukan oleh Allah, disebut jar mah hud $d, 2$ ) tindak pidana yang sanksinya dominan ditentukan oleh Allah, tetapi haknya lebih ditekankan kepada manusia, disebut jar mah qis s-diyat, dan 3) tindak pidana yang sanksinya merupakan kompetensi pemerintah untuk menentukannya, disebut jar mah ta'zîr. ${ }^{29}$

\footnotetext{
${ }^{27}$ Suharto, Hukum Pidana Materiil (Jakarta: Sinar Grafika, 2002), 5.

${ }^{28}$ S.R. Sianturi, Asas-asas Hukum Pidana di Indonesia dan Penerapannya (Jakarta: PBK.Gunung Mulia, 1996), 13.

29 Ahmad Wardi Muslich, Pengantar dan Asas Hukum Pidana Islam Fikih Jinayat (Jakarta: Sinar Grafika, 2004), 18.
} 
Jar mah hud $d$ adalah suatu jar mah (tindak pidana) yang diancam padanya hukuman had, yaitu hukuman yang telah ditentukan macam danjumlahnya yang menjadi hak Allah. Jar mah hud $d$ ada 7 (tujuh) macam, yaitu: zina, qazaf (menuduh berzina), sakr (minumminuman keras), sariqah (pencurian), hir bah (perampokan), riddah (keluar dari Islam) dan bugh $h$ (pemberontakan). ${ }^{30}$

Jar mah qis $s$ dan diat adalah jar mah yang diancam dengan hukuman qis $s$ atau diat. Baik qis $s$ maupun diat keduanya adalah hukuman yang sudah ditentukan oleh syara'. Perbedaannya dengan hukuman had adalah bahwa had merupakan hak Allah (hak masyarakat), sedangkan qis $s$ dan diat adalah hak manusia (individu). ${ }^{31}$

Hak manusia adalah yang ada hubungannya dengan kepentingan pribadi seseorang dan dinamakan begitu karena kepentingannya khusus untuk mereka. Dalam hubungannya dengan hukuman qis $s$ dan diat, maka pengertian hak manusia di sini adalah bahwa hukuman tersebut bisa dihapuskan atau dimaafkan oleh korban atau keluarganya. ${ }^{32}$

Dalam suatu tindak pidana dapat dihapuskan suatu hukuman atas tindak pidana dengan beberapa unsur sebagai berikut:

a. Hukum Paksaan

Hukum paksaan dapat berbeda-beda menurut perbedaan perbuatan yang terjadi. Dalam konteks ini perbuatan-perbuatan tersebut dapat dikelompokkan menjadi tiga kelompok, sebagai berikut:

(1) Perbuatan yang tidak dipengaruhi oleh paksaan

Perbuatan yang tidak bisa dipengaruhi oleh paksaan sama sekali, meskipun paksaan absolut adalah pembunuhan dan penganiayaan berat (pemotongan anggota badan, pukulan yang berat, dan sebagainya). Dalam firman Allah QS. Al-Ahzab ayat 58 sebagai berikut:

"Dan orang-orang yang menyakiti orang-orang mukmin dan mukminat tanpa kesalahan yang mereka perbuat maka sesungguhnya mereka telah memikul kebohongan dan dosa yang nyata." ${ }^{33}$ (QS. Al-Ahzab: 58)

\footnotetext{
${ }^{30}$ Ibid. 19.

${ }^{31}$ Ibid., 21.

${ }^{32}$ Syeikh Mahmud Syaltut, al-Islâm Aqîdah wa Sharîah, terj. Fachruddin HS (Jakarta: Bina Aksara, 1985), 14.

${ }^{33}$ Departemen Agama RI, Al-Qur'an Tajwid dan Terjemahannya (Bandung: Syaamil Cipta Media, 2006), 114.
} 
(2) Perbuatan yang diperbolehkan karena adanya paksaan

Perbuatan-perbuatan yang termasuk kelompok ini hanya berhubungan dengan masalah makanan dan minuman yang diharamkan, seperti makan bangkai, makan daging babi, minum darah, dan barang-barang yang najis, sedangkan paksaannya bersifat absolut. Makanan makanan yang telah disebutkan semuanya diharamkan, tetapi kalau keadaannya terpaksa atau dipaksa maka hukumnya dibolehkan. ${ }^{34}$ Alasannya adalah firman Allah swt dalam QS. Al-Baqarah : 173:

"Sesungguhnya Allah hanya mengharamkan bagimu bangkai, darah, daging babi, dan binatang yang (ketika disembelih) disebut (nama) selain Allah, tetapi barangsiapa dalam keadaan terpaksa (memakannya) sedang dia tidak menginginkannya dan tidak (pula) melampaui batas, maka tidak ada dosa baginya. Sesungguhnya Allah Maha Pengampun lagi Maha Penyayang. ${ }^{35}$

Dari ayat tersebut jelaslah bahwa makanan yang semula diharamkan dalam keadaan terpaksa hukumnya dibolehkan. Demikian pula halnya orang yang dipaksa. Dengan demikian, baik orang yang terpaksa maupun orang yang dipaksa memakan makanan yang diharamkan, ia tidak dibebani pertanggung-jawaban pidana dan perdata. Untuk mengetahui secara rinci tentang perbuatan-perbuatan yang termasuk dalam kelompok ini, perlu dilakukan penelitian terhadap nas-nas yang melarang perbuatan-perbuatan tersebut. Kalau perbuatan-perbuatan tersebut dibolehkan dalam keadaan terpaksa (darurat) atau dipaksa, perbuatan tersebut termasuk dalam kelompok ini. Akan tetapi, apabila tidak dibolehkan maka tidak termasuk dalam kelompok ini.

(3) Perbuatan yang diperbolehkan sebagai pengecualian

Selain perbuatan-perbuatan yang disebutkan pada bagian pertama dan kedua, paksaan absolut dapat menghapuskan hukuman, baik paksaan materiil maupun paksaan moril ma'nawi walaupun perbuatan yang dilakukan oleh orang yang dipaksa tetap dilarang. Alasan pembebasan hukuman dalam perbuatan-perbuatan tersebut adalah bahwa pelaku ketika melakukan perbuatannya tidak mempunyai kehendak dan pilihan yang sebenarnya, sedangkan dasar pertanggung jawaban itu adalah adanya kehendak dan pilihan.

\footnotetext{
${ }^{34}$ Syeikh Mahmud Syaltut, al-Islâm Aqîdah wa Sharîah, 18.

${ }^{35}$ Departemen Agama RI, Al-Qur'an Tajwid dan Terjemahannya, 94.
} 
Dengan demikian, sebab dari pembebasan hukuman tersebut berkaitan dengan pribadi orang yang melakukannya, bukan dengan perbuatannya itu sendiri. Itulah sebabnya maka pelaku dibebaskan dari hukuman sedangkan perbuatannya tetap dilarang. ${ }^{36}$

Pertanggungjawaban perdata yang timbul akibat perbuatan tersebut tetap dikenakan kepada pelaku perbuatan tersebut, meskipun ia dibebaskan dari pertanggungjawaban pidana, karena menurut aturan dan kaidah pokok dalam syariat Islam, jiwa dan harta itu dilindungi oleh negara. Oleh karena itu, penyerangan terhadapnya dilarang dan alasan-alasan dari syara' tidak dapat menghapuskan hak perlindungan tersebut. Jar mah-jar mah yang termasuk dalam kelompok ketiga ini, antara lain seperti penuduhan zina, penghinaan, pencurian, merusak harta milik orang lain, zina, dan sebagainya. Sebagian fuqaha sebagaimana dikutip oleh Abdul Qadir Audah, memberikan definisi sebagai berikut. "Paksaan adalah suatu perbuatan yang dilakukan oleh seseorang karena orang lain, dan oleh karena itu hilanglah kerelaannya atau tidak sempurna pilihannya. Atau paksaan adalah suatu perbuatan yang timbul dari orang yang memaksa dan menimbulkan pada diri orang yang dipaksa suatu keadaan yang mendorong dirinya untuk mengerjakan perbuatan yang dimintakan kepadanya. Atau paksaan adalah ancaman oleh seseorang atas orang lain dengan sesuatu yang tidak disenangi untuk mengerjakan sesuatu sehingga karenanya hilang kerelaannya. ${ }^{37}$

Sebagian fuqaha yang lain mengemukakan definisi sebagai berikut: "paksaan adalah sesuatu yang ditimpakan kepada orang lain yang membahayakannya atau menyakitinya". Sebagian lagi berpendapat bahwa definisi paksaan, adalah paksaan adalah ancaman berupa hukuman segera dari orang yang memaksa yang mampu untuk melaksanakan paksaannya dan karenanya mempengaruhi orang berakal sehat untuk mengerjakan apa yang dipaksakan padanya serta timbul dugaan kuat pada dirinya bahwa ancaman tersebut akan benar-benar dikenakan padanya, apabila ia menolak apa yang dipaksakan kepadanya. ${ }^{38}$

\footnotetext{
${ }^{36}$ Syeikh Mahmud Syaltut, al-Islâm Aqîdah wa Sharîah, 21.

${ }^{37}$ Abd al-Qadir Audah, al-Tashrî' al-Jinâ'î al-Islâmy (Mesir: Dar al-Fikr al-Araby, tth), 563.

${ }^{38}$ Ibid., 565.
} 
Dari definisi-definisi yang dikemukakan di atas dapat diambil intisari bahwa paksaan adalah suatu upaya yang dilakukan oleh seseorang untuk mempengaruhi orang lain agar ia melakukan apa yang diinginkan olehnya (pemaksa) dengan menggunakan ancaman. Sebagai akibat dari adanya ancaman tersebut, pihak yang dipaksa tidak mempunyai pilihan lain, kecuali mengerjakan apa yang diinginkan oleh pihak yang memaksa. Itulah sebabnya orang yang dipaksa kehilangan kerelaan dan pilihan.

Para fuqaha berbeda pendapat mengenai jenis hukuman yang harus dijatuhkan kepada pelaku. Menurut Imam Malik dan Imam Ahmad hukumannya adalah sama karena sudah cukup jelas dan tidak ada syubhat. Sedangkan menurut ulama Syafi'iyah dan Hanafiah, sebagian menyatakan hukumannya adalah sama dengan syariat dan sebagian lagi menyatakan hukumannya adalah diat. Alasan golongan kedua ini adalah karena adanya paksaan itu dianggap sebagai syubhat yang dapat menghapuskan hukuman. Imam Abu Hanifah sendiri dan muridnya Imam Muhammad ibn Hasan, hanya menetapkan hukuman ta'zîr. ${ }^{39}$

b. Unsur Memabukkan

Syariat Islam melarang minuman keras, baik sampai mengakibatkan mabuk maupun tidak. Dalam kelompok jar mah, minuman keras termasuk jar mah hud $d$ yang ancamannya adalah delapan puluh kali cambukan. Kecuali Imam Abu Hanifah dan muridmuridnya, para ulama telah sepakat semua jenis minuman yang memabukkan, baik disebut khamar atau bukan, sedikit atau banyak, hukumnya tetap dilarang dan peminumnya dikenakan hukuman. Akan tetapi, menurut Imam Abu Hanifah dalam hal ini harus dibedakan antara khamar dengan minuman keras yang lain. Untuk minuman khamar, sedikit atau banyak, baik mabuk atau tidak, tetap dihukum, sedangkan untuk minuman keras selain khamar, baru dihukum apabila sampai memabukkan. Bahan minuman khamar itu adalah perasan anggur yang direbus sampai kemudian hilang kurang dua pertiganya. ${ }^{40}$

Secara umum yang dimaksud dengan mabuk adalah hilangnya akal sebagai akibat minum minuman keras atau khamar atau yang sejenisnya. Menurut Imam Abu Hanifah, seorang dikatakan mabuk,

\footnotetext{
39 Ibid., 570.

${ }^{40}$ Ahmad Hanafi, Asas-Asas Hukum Pidana Islam (Jakarta: Bulan Bintang, 1990), 365.
} 
apabila ia telah kehilangan akal pikirannya, baik banyak atau sedikit, ia tidak dapat membedakan antara langit dengan bumi, dan antara laki-laki dengan perempuan. Sedangkan Muhammad ibn Hasan dan Imam Abu Yusuf berpendapat bahwa orang mabuk itu adalah orang yang banyak mengigau pada pembicaraannya. Pendapat ini juga merupakan pendapat imam-imam yang lain. Alasan mereka ini adalah firman Allah dalam QS. an-Nisa': 43:

"Hai orang-orang yang beriman, janganlah kamu shalat, sedang kamu dalam keadaan mabuk, sehingga kamu mengerti apa yang kamu ucapkan, (jangan pula hampiri masjid) sedang kamu dalam keadaan junub, terkecuali sekedar berlalu saja, hingga kamu mandi. Dan jika kamu sakit atau sedang dalam musafir atau datang dari tempat buang air atau kamu telah menyentuh perempuan, kemudian kamu tidak mendapat air, maka bertayamumlah kamu dengan tanah yang baik (suci); sapulah mukamu dan tanganmu. Sesungguhnya Allah Maha Pema'af lagi Maha Pengampun." 41

Dari ayat tersebut jelaslah bahwa orang yang tidak mengetahui apa yang dikatakannya berarti ia sedang mabuk. Adapun pertanggung jawaban pidana bagi orang yang mabuk, menurut pendapat yang kuat dari ulama mazhab yang empat, ia tidak dijatuhi hukuman atas jar mahjar mah yang dilakukannya, apabila ia dipaksa atau terpaksa untuk minum atau ia meminumnya atas kehendak sendiri, tetapi ia tidak mengetahui bahwa yang diminumnya itu adalah khamar atau ia meminum-minuman keras untuk berobat, lalu ia mabuk. Orang yang sedang mabuk tersebut ketika ia melakukan perbuatannya, sedang hilang akal pikiran dan kesadarannya, sehingga dengan demikian maka hukumnya sama dengan orang gila. Akan tetapi, jika seseorang minum minuman keras karena kemauan sendiri dengan sengaja tanpa alasan, atau ia meminumnya sebagai obat yang sebenarnya tidak diperlukan kemudian ia mabuk, dalam hal ini ia harus bertanggung jawab atas setiap jar mah yang dilakukannya ketika ia mabuk. Hukuman tersebut diberikan kepadanya sebagai pengajaran, karena ia telah menghilangkan akalnya sendiri secara sengaja. ${ }^{42}$

Di samping pendapat yang kuat tersebut, di kalangan ulama mazhab yang empat ada pendapat yang tidak kuat yaitu bahwa orang

${ }_{41}^{41}$ Departemen Agama RI, Al-Qur'an Tajwid dan Terjemahannya, 94.

${ }^{42}$ Ahmad Hanafi, Asas-Asas Hukum Pidana Islam, 373. 
yang mabuk tidak dibebani pertanggungjawaban atas semua perbuatan jar mah yang dilakukannya, bagaimanapun terjadinya dan apa pun sebab mabuknya itu, karena pada saat itu akal pikirannya sedang hilang. Ini berarti orang yang mabuk tersebut tidak menyadari perbuatannya, sedang kesadaran merupakan dasar adanya pertanggung jawaban pidana. Mengenai pertanggungjawaban perdata orang yang mabuk tetap dikenakan, sebab jiwa dan harta orang lain tetap harus dijamin keselamatannya dan pembebasan dari hukuman pidana tidak mempengaruhi hukuman perdata. ${ }^{43}$

c. Gila

Syariat Islam memandang seseorang sebagai orang mukallaf yang dapat dibebani pertanggungjawaban pidana, apabila ia memiliki kemampuan berpikir dan memilih (idr $k$ dan $i k h t i r$ ). Apabila salah satu dari kedua perkara ini tidak ada maka pertanggungjawaban menjadi terhapus. Kemampuan berpikir seseorang itu dapat hilang karena faktor bawaan sejak lahir atau karena adanya gangguan seperti sakit atau cacat fisik. Hilangnya kemampuan berpikir tersebut dalam bahasa sehari-hari disebut gila. Abdul Qadir Audah memberikan definisi gila sebagai berikut "Gila adalah hilangnya akal, rusak, atau lemah". ${ }^{44}$

Definisi tersebut merupakan definisi yang umum dan luas, sehingga mencakup gila, dungu, dan semua jenis penyakit kejiwaan yang sifatnya menghilangkan idrak (kemampuan berpikir). Di bawah ini akan dijelaskan jenis-jenis penyakit, baik yang menghilangkan seluruh kekuatan berpikir maupun sebagiannya. Beberapa bentuk gila dan keadaan-keadaan lain yang sejenis:

1) Gila terus-menerus

Gila terus-menerus adalah suatu keadaan di mana seseorang tidak dapat berpikir sama sekali, baik hal itu diderita sejak lahir maupun yang datang kemudian. ${ }^{45}$

2) Gila berselang

Orang yang terkena penyakit gila berselang tidak dapat berpikir, tetapi tidak terus-menerus. Apabila keadaan tersebut menimpanya maka ia kehilangan pikirannya sama sekali, dan apabila keadaan tersebut telah berlalu (hilang) maka ia dapat

\footnotetext{
${ }^{43}$ Ibid., 380.

${ }^{44}$ Abd al-Qadir Audah, al-Tashrî́ al-Jinâî̂ al-Islâmy, 564.

${ }^{45}$ Ibid., 566.
} 
berpikir kembali seperti biasa. Pertanggungjawaban pidana pada gila terus-menerus hilang sama sekali, sedangkan pada gila berselang ia tetap dibebani pertanggungjawaban ketika ia dalam kondisi sehat. ${ }^{46}$

3) Gila sebagian

Gila sebagian menyebabkan seseorang tidak dapat berpikir dalam perkara-perkara tertentu, sedangkan pada perkara-perkara yang lain ia masih tetap dapat berpikir. Dalam kondisi di mana ia masih dapat berpikir, ia tetap dibebani pertanggungjawaban pidana, tetapi ketika ia tidak dapat berpikir, ia bebas dari pertanggungjawaban pidana. ${ }^{47}$

4) Dungu

Para fuqaha sebagaimana dikutip oleh Abdul Qadir Audah memberikan definisi orang dungu sebagai berikut. "Orang dungu adalah orang yang minim pemahamannya, pembicaraannya bercampur baur, tidak beres pemikirannya, baik hal itu bawaan sejak lahir atau timbul kemudian karena suatu penyakit". ${ }^{48}$

Dari definisi tersebut dapat dipahami bahwa dungu merupakan tingkatan gila yang paling rendah. Dengan demikian, dungu berbeda dengan gila, karena dungu hanya mengakibatkan lemahnya berpikir bukan menghilangkannya, sedangkan gila mengakibatkan hilangnya atau kacaunya kekuatan berpikir, sesuai dengan tingkatan-tingkatan kedunguannya, namun orang yang dungu bagaimanapun tidak sama kemampuan berpikirnya dengan orang biasa (normal). Menurut sebagian fuqaha kekuatan berpikir orang dungu sama dengan orang yang sudah mumayyiz (lebih kurang berumur antara tujuh sampai lima belas tahun), sedang menurut sebagian yang lain sama dengan anak yang belum mumayyiz. Karena pemikirannya yang tidak stabil itu, secara umum orang yang dungu tidak dibebani pertanggungjawaban pidana.

Pengaruh gila terhadap pertanggungjawaban pidana tidak sama, tergantung apakah gilanya itu menyertai jar mah atau sesudahnya. Apabila gila menyertai perbuatan jar mah (yaitu ketika melakukan

\footnotetext{
${ }^{46}$ Ibid., 567.

${ }^{47} \mathrm{lbid}$.

${ }^{48} \mathrm{lbid}$, 568.
} 
jar mah pelaku sudah gila), maka pelakunya dibebaskan dari pertanggungjawaban pidana, karena pada saat melakukan jar mah ia tidak mempunyai kekuatan berpikir. Keadaan gila ini tidak menjadikan suatu jar mah dibolehkan, melainkan hanya menghapuskan hukuman dari pelakunya. Ketentuan ini sudah merupakan kesepakatan para fuqaha dan juga para sarjana hukum positif. Dalam Pasal 44 KUHP dinyatakan:

(1) Tiada dapat dipidana barangsiapa mengerjakan suatu perbuatan yang tidak dapat dipertanggungjawabkan kepadanya, sebab kurang sempurna akalnya atau sakit berubah akal.

(2) Jika nyata perbuatan itu tidak dapat dipertanggungjawabkan padanya sebab kurang sempurna akalnya atau sakit berubah akal, maka dapatlah hakim memerintahkan memasukkan dia ke rumah sakit jiwa selama-lamanya satu tahun untuk diperiksa. ${ }^{49}$

Akan tetapi pembebasan orang gila dari hukuman, tidak berarti ia dibebaskan juga dari pertanggungjawaban perdata, sebab harta benda dan jiwa orang lain dijamin keselamatannya oleh syara' dan alasan-alasan yang sah tidak dapat menghilangkan jaminan tersebut. Sebagaimana orang gila masih tetap memiliki harta benda, ia juga dapat dibebani pertanggungjawaban perdata, yaitu pertanggungjawaban yang berkaitan dengan harta. Meskipun para fuqaha sepakat mengenai adanya pertanggungjawaban perdata yang penuh atas orang gila sebagai akibat perbuatannya, namun mereka berbeda pendapat mengenai sejauh mana besarnya pertanggungjawaban tersebut dalam jar mah pembunuhan dan penganiayaan. Perbedaan tersebut berpangkal pada perbedaan pendapat mereka tentang kesengajaan orang gila, apakah dianggap sengaja dalam arti yang sesungguhnya atau dianggap sebagai kekeliruan semata-mata. Menurut Imam Malik, Imam Abu Hanifah, dan Imam Ahmad perbuatan sengaja dari orang gila itu termasuk tidak sengaja, karena ia tidak mungkin melakukan perbuatan itu dengan niat yang sesungguhnya. Sedangkan menurut Imam Syafi'i, perbuatan sengaja dari orang gila termasuk kesengajaan dan bukan kesalahan, karena gila itu hanya membebaskan hukuman, tetapi tidak mengubah sifat perbuatannya. ${ }^{50}$

\footnotetext{
${ }^{49}$ Citra Umbara, Kitab Undang-Undang Hukum Pidana (Bandung: Citra Umbara, 2009), 29.

${ }^{50}$ Ahmad Hanafi, Asas-Asas Hukum Pidana Islam, 383.
} 
Perbedaan pendapat tentang status perbuatan orang gila tersebut berpengaruh terhadap penggantian kerugian yang harus dipikulnya. Hal ini oleh karena diat pada jar mah sengaja adalah diat mughallazah (yang diperberat) dan harus ditanggung sendiri oleh pelaku, sedangkan diat pada jar mah tidak sengaja (khatha) adalah diat mukhaffafah (yang diperingan) dan ditanggung oleh keluarga ('aqilah) dan pelaku bersamasama.

Imam Abu Hanifah berpendapat apabila keadaan gila timbul setelah terhukum diserahkan untuk dilaksanakan hukumannya maka hukuman tersebut tidak boleh ditunda. Apabila hukumannya berupa qis $s$ dan terhukum menjadi gila setelah diserahkan untuk dieksekusi, hukuman qis $s$ diganti dengan diat dengan menggunakan istihsan. Pendirian tentang ditundanya hukuman untuk orang gila, didasarkan atas dua alasan:

(1) Penjatuhan hukuman harus didasarkan atas adanya taklif pada diri terhukum dan hukuman tidak akan terjadi kecuali dengan proses pemeriksaan. Dengan demikian, syarat taklif (kecakapan) harus ada pada waktu pemeriksaan dan keputusan hukuman.

(2) Pelaksanaan hukuman atau eksekusi termasuk kelanjutan dari proses peradilan. Apabila syarat taklif harus terdapat pada waktu dilakukannya pemeriksaan oleh hakim, syarat ini juga harus terdapat pada saat dilaksanakannya keputusan hakim, sedang dengan adanya gila maka taklif tersebut menjadi hapus. ${ }^{51}$

d. Masih di Bawah Umur

Konsep yang dikemukakan oleh syari'at Islam tentang pertanggungjawaban anak di bawah umur merupakan konsep yang sangat baik. Meskipun konsep tersebut telah lama usianya, namun konsep tersebut menyamai teori terbaru di kalangan hukum positif. Hukum Romawi sebagai bentuk hukum positif yang paling maju pada masa turunnya syariat Islam dan yang menjadi dasar hukum-hukum Eropa modern, mengadakan pemisahan antara pertanggungjawaban anak dibawah umur dengan pertanggungjawaban orang dewasa dalam batas yang sangat sempit, yaitu usia tujuh tahun. Dengan demikian menurut hukum Romawi, apabila anak-anak telah mencapai umur tujuh tahun ke atas maka ia dibebani pertanggungjawaban pidana. Akan tetapi apabila seorang anak belum mencapai usia tersebut (tujuh tahun), ia tidak

51 Ibid., 357. 
dikenakan pertanggungjawaban pidana, kecuali kalau ketika melakukan jar mah ia mempunyai niatan untuk merugikan orang lain. Dalam hal yang terakhir ini, meskipun ia belum mencapai usia tujuh tahun, tetap dikenakan pertanggungjawaban pidana. Pandangan hukum Romawi mi tentu saja sangat jauh berbeda dengan konsep yang dibawa oleh syariat Islam.

Menurut syariat Islam, pertanggungjawaban pidana didasarkan atas dua perkara, yaitu kekuatan berpikir dan pilihan. Sehubungan dengan kedua dasar tersebut, maka kedudukan anak di bawah umur berbeda-beda sesuai dengan perbedaan masa yang dilaluinya dalam kehidupannya, semenjak ia dilahirkan sampai ia memiliki kedua perkara tersebut.

Secara alamiah terdapat tiga masa yang dialami oleh setiap orang sejak ia dilahirkan sampai ia dewasa. (1) Masa Tidak Adanya Kemampuan Berpikir, (2) Masa Kemampuan Berpikir yang Lemah; (3) Masa Kemampuan Berpikir Penuh.

\section{Analisis terhadap Penghapusan Pidana bagi Pejabat Negara Penerima Gratifikasi}

Perbuatan gratifikasi masuk dalam unsur delik yang bukan hanya memiliki sifat melawan hukum formil, melainkan terdapat unsur melawan hukum materiil, karena berdampak luas pada sistem yang ada dalam kelembagaan para pegawai negeri atau pejabat, baik di ranah legislatif maupun eksekutif. Namun, pemberian yang memiliki makna luas tersebut sulit untuk dideteksi apakah hal tersebut berkaitan dengan jabatan atau kewenangan yang dimiliki atau memang pemberian tersebut merupakan suatu bentuk reward atau penghargaan ataukah bisa dikatakan untuk meningkatkan kualitas SDM dan kinerja agar lebih profesional. Hal inilah yang membuat para penyidik atau penuntut harus lebih tajam dan dalam untuk menggali apakah perbuatan memberikan sesuatu dalam konteks luas itu masuk dalam klasifikasi gratifikasi atau bukan.

Salah satu kebiasaan yang berlaku umum di masyarakat adalah pemberian tanda terima kasih atas jasa yang telah diberikan oleh petugas, baik dalam bentuk barang atau bahkan uang. Hal ini dapat menjadi suatu kebiasaan yang bersifat negatif dan dapat mengarah menjadi potensi perbuatan korupsi di kemudian hari. 
Potensi korupsi inilah yang berusaha dicegah oleh peraturan Undang-Undang. Oleh karena itu, berapapun nilai gratifikasi yang diterima seorang Penyelenggara Negara atau Pegawai Negeri, disini diperlukan kepekaan pejabat kepada Pasal $12 \mathrm{C}$ ayat (3), maka sebaiknya Penyelenggara Negara atau Pegawai Negeri tersebut segera melaporkan pada KPK untuk dianalisis lebih lanjut. Jadi dapat dikatakan bahwa tidak benar bila Pasal 12 B dalam Undang-Undang Nomor 31 Tahun 1999 juncto Undang-Undang Nomor 20 Tahun 2001 telah melarang praktik gratifikasi atau pemberian hadiah di Indonesia. Sesungguhnya, praktik gratifikasi atau pemberian hadiah di kalangan masyarakat tidak dilarang tetapi perlu diperhatikan adanya sebuah rambu tambahan yaitu larangan bagi pegawai negeri/penyelenggara negara untuk menerima gratifikasi yang dapat dianggap suap.

Penerimaan gratifikasi oleh penyelenggara negara atau pegawai negeri dan keluarganya dalam suatu acara pribadi, atau menerima pemberian suatu fasilitas tertentu yang tidak wajar, semakin lama akan menjadi kebiasaan yang cepat atau lambat akan mempengaruhi penyelenggara negara atau pegawai negeri yang bersangkutan. Banyak yang berpendapat bahwa pemberian tersebut sekedar tanda terima kasih dan sah-sah saja, tetapi pemberian tersebut patut diwaspadai sebagai pemberian yang berpotensi menimbulkan konflik kepentingan karena terkait dengan jabatan yang dipangku oleh penerima serta kemungkinan adanya kepentingan-kepentingan dari pemberi, dan pada saatnya pejabat penerima akan berbuat sesuatu untuk kepentingan pemberi sebagai balas jasa.

Untuk memudahkan dalam konteks apakah gratifikasi yang diterima termasuk suatu pemberian hadiah yang ilegal atau legal, maka penulis memberikan ilustrasi sebagai berikut: Jika seorang ibu penjual makanan di sebuah warung memberi makanan kepada anaknya yang datang ke warung, maka itu merupakan pemberian keibuan. Pembayaran dari si anak bukan suatu yang diharapkan oleh si ibu. Balasan yang diharapkan lebih berupa cinta kasih anak, dan berbagai macam balasan lain yang mungkin diberikan. Kemudian datang seorang pelanggan, si ibu memberi makanan kepada pelanggan tersebut lalu menerima pembayaran sebagai balasannya. Keduanya tidak termasuk gratifikasi ilegal. Pada saat lain, datang seorang inspektur kesehatan dan si ibu memberi makanan kepada si inspektur serta menolak menerima 
pembayaran. Tindakan si ibu menolak menerima pembayaran dan si inspektur menerima makanan ini adalah gratifikasi ilegal karena pemberian makanan tersebut memiliki harapan bahwa inspektur itu akan menggunakan jabatannya untuk melindungi kepentingannya. Andaikan inspektur kesehatan tersebut tidak memiliki kewenang dan jabatan lagi, akankah si ibu penjual memberikan makanan tersebut secara cumacuma?

Dengan adanya pemahaman ini, maka seyogyanya masyarakat tidak perlu tersinggung seandainya pegawai negeri/penyelenggara negara menolak suatu pemberian, hal ini dilakukan dikarenakan kesadaran terhadap apa yang mungkin tersembunyi di balik gratifikasi tersebut dan kepatuhannya terhadap peraturan perundangan. Realitas yang ada di sekitar kita menunjukkan betapa suburnya praktik suap dan gratifikasi dalam konteks negara Indonesia yang mengindikasikan bobroknya mental dan moral para pejabat di negeri ini.

Penulis berpendapat para pejabat atau pegawai negeri bisa berlindung di balik Pasal 12 C Undang-Undang No. 20 tahun 2001 yang semata-mata melapor saja ke KPK, namun kelanjutan dari laporan semuanya tidak ada yang tahu apakah tetap berlanjut ke penyidikan ataukah berhenti karena sakit, pergi ke luar negeri atau alasan-alasan lainnya yang menyebabkan dihentikan untuk sementara proses penyelidikan dan penyidikan. Hal itulah mengapa perbuatan gratifikasi seringkali di lapangan sangat sulit utuk dideteksi, apalagi pihak penerima akan melapor ke KPK seketika itu.

Dalam kaca mata hukum pidana Islam, aturan pidana tambahan dalam Undang-Undang Pemberantasan Tindak Pidana Korupsi juga merepresentasikan penerapan maslahat. Secara teoretis, diakui bahwa aturan pidana tambahan tersebut telah mempertimbangkan aspek rasionalitas, yakni didasarkan pada tujuan pemidanaan berupa pemenuhan rasa keadilan masyarakat dan sarana perlindungan masyarakat. Hal ini jelas merupakan wujud dari komponen maslahat, yakni jalb al-masâlih wa dar' al-mafâsid, di mana kepentingan yang dilindungi ialah kepentingan hidup masyarakat (maslahah 'âmmah). Ini merupakan bentuk aplikasi maslahat dalam formulasi aturan pidana tambahan dalam Undang-Undang Pemberantasan Tindak Pidana Korupsi, khususnya perbuatan gratifikasi. 
Gratifikasi yang diberikan terhadap pejabat negara termasuk tindakan melawan hukum dalam pandangan hukum positif maupun fikih jin yah. Dalam hukum positif tertuang pada pasal 12 B UndangUndang No. 31 Tahun 1999 jo. Undang-Undang No. 20 Tahun 2001 tentang Pemberantasan Tindak Pidana Korupsi. Sedangkan, dalam fikih jin yah gratifikasi di definisikan sebagai al-rishwah.

Hadiah kepada pejabat adalah suatu pemberian dari seseorang dan/atau masyarakat yang diberikan kepada pejabat, karena kedudukannya, baik pejabat di lingkungan pemerintahan maupun lainnya. Kemudian masalah hukum memberikan risywah dan menerima hukumnya adalah haram. Melakukan korupsi hukumnya adalah haram. Memberikan hadiah kepada pejabat: Jika pemberian hadiah itu pernah diperhatikan pula konsiderans "Menimbang" Undang-Undang No. 31 Tahun 1999 tentang Pemberantasan Tindak Pidana Korupsi, dan konsiderans "Menimbang" Undang-Undang RI No. 20 Tahun 2001 tentang Perubahan atas Undang-Undang No. 31 Tahun 1999 tentang Pemberantasan Tindak Pidana Korupsi dilakukan sebelum pejabat tersebut memegang jabatan, maka pemberian seperti itu hukumnya halal (tidak haram), demikian juga menerimanya; b. Jika pemberian hadiah itu tidak pernah dilakukan sebelum pejabat tersebut memegang jabatan, maka dalam hal ini ada tiga kemungkinan:

1. Jika antara pemberi hadiah dan pejabat tidak ada atau tidak akan ada urusan apa-apa, maka memberikan dan menerima hadiah tersebut tidak haram;

2. Jika antara pemberi hadiah dan pejabat terdapat urusan (perkara), maka bagi pejabat haram menerima hadiah tersebut; sedangkan bagi pemberi, haram memberikannya apabila pemberian dimaksud bertujuan untuk meluluskan sesuatu yang batil (bukan haknya);

3. Jika antara pemberi hadiah dan pejabat ada sesuatu urusan, baik sebelum maupun sesudah pemberian hadiah dan pemberiannya itu tidak bertujuan untuk sesuatu yang batil, maka halal (tidak haram) bagi pemberi memberikan hadiah itu, tetapi bagi pejabat haram menerimanya.

Dalam kaca mata hukum pidana Islam, aturan pidana tambahan dalam Undang-Undang Pemberantasan Tindak Pidana Korupsi juga merepresentasikan penerapan maslahat. Secara teoretis, diakui bahwa aturan pidana tambahan tersebut telah mempertimbangkan aspek 
rasionalitas, yakni didasarkan pada tujuan pemidanaan berupa pemenuhan rasa keadilan masyarakat dan sarana perlindungan masyarakat. Hal ini jelas merupakan wujud dari komponen maslahat, yakni jalb al-masâlih wa dar' al-mafâsid, di mana kepentingan yang dilindungi ialah kepentingan hidup masyarakat (maslahah âmmah). Ini merupakan bentuk aplikasi maslahat dalam formulasi aturan pidana tambahan dalam Undang-Undang Pemberantasan Tindak Pidana Korupsi, khususnya perbuatan gratifikasi.

Sesuai dengan kaidah ushuliyah bahwa jalb al-masâlih wa dar' almafâsid atau mengambil kemanfaatan atau mashlahat dan menolak segala mafsadat atau kerusakan menjadi dasar patokan bahwa penerima gratifikasi yang melapor kepada Komisi Pemberantasan Korupsi (KPK) itu guna mengambil manfaat, yakni agar tidak menimbulkan perbuatan korupsi dan gratifikasi yang lebih besar lagi dan merugikan negara.

Analisis penulis terhadap fatwa MUI yang mengharamkan perbuatan gratifikasi ketika pemberian hadiah itu pernah dilakukan sebelum pejabat tersebut memegang jabatan, maka pemberian seperti itu hukumnya halal (tidak haram), demikian juga menerimanya, kemudian ketika pemberian hadiah itu tidak pernah dilakukan sebelum pejabat tersebut memegang jabatan, maka sifatnya relatif. Artinya melihat tujuan dari pemberian hadiah itu. Apakah pemberian itu mempunyai maksud tertentu atau tidak. Kalau antara pemberi hadiah dan pejabat terdapat urusan (perkara), maka bagi pejabat haram menerima hadiah tersebut. Kemudian bagi pemberi, haram memberikannya apabila pemberian dimaksud bertujuan untuk meluluskan sesuatu yang batil (bukan haknya) dan ketika antara pemberi hadiah dan pejabat ada sesuatu urusan, baik sebelum maupun sesudah pemberian hadiah dan pemberiannya itu tidak bertujuan untuk sesuatu yang batil, maka halal (tidak haram) bagi pemberi memberikan hadiah itu, tetapi bagi pejabat haram menerimanya.

Hukum Islam memandang ketika penerima melapor ke Komisi Pemberantasan tindak pidana Korupsi akan bermanfaat, baik bagi dirinya ataupun orang lain atau masyarakat luas. Ketika penerima gratifikasi tidak melaporkan ke komisi tersebut, maka akan berdampak buruk bagi si penerima maupun orang lain. Dampak buruk bagi si penerima yaitu akan diproses hukum sesuai dengan ketentuan perUndang-Undangan dan tentunya tidak akan bermanfaat bagi dirinya. 
Lalu dampak buruk bagi pihak lain, yaitu berupa terampasnya hak-hak orang lain untuk berbuat sesuatu, karena sudah diberikan hadiah, maka orang lain harus tunduk kepada orang yang memberi hadiah tersebut dan hal ini sangat merugikan banyak pihak.

Faktor-faktor baik internal maupun eksternal sangat mempengaruhi si pemberi dan penerima gratifikasi pada setiap momentum tertentu, seperti perkawinan atau saat hari raya dengan memberikan parcel atau hadiah dan pemberian itu ternyata dimaksudkan untuk melakukan sesuatu yang melebihi batas-batas kewenangannya sebagai seorang pejabat. Dampak buruk lainnya akan menimbulkan saling curiga pejabat satu dengan lainnya dalam satu kantor, yang akhirnya terjadi perselisihan dan dibawa oleh koleganya sendiri ke ranah hukum. Hal ini dipandang hukum Islam sebagai perbuatan yang merugikan orang lain. Sebab kaidahnya mengatakan "jangan membuat kerusakan pada diri sendiri dan orang lain”, yang sangat tepat ketika dihubungkan dengan perbuatan memberi hadiah kepada pejabat atau baik si pemberi maupun si penerima gratifikasi. Penerima dan pemberi dalam konteks inilah perbuatan yang merusak diri sendiri dan orang lain.

Hukuman yang diberikan terhadap penerima gratifikasi dalam hukum positif sebagaimana tercantum dalam pada pasal 12 B UndangUndang No. 31 Tahun 1999 jo. Undang-Undang No. 20 Tahun 2001 tentang Pemberantasan Tindak Pidana Korupsi yakni pidana penjara seumur hidup atau pidana penjara paling singkat 4 (empat) tahun dan paling lama 20 (dua puluh) tahun, dan pidana denda paling sedikit Rp 200.000.000,00 (dua ratus juta rupiah) dan paling banyak Rp 1.000.000.000,00 (satu miliar rupiah). Sedangkan dalam fikih jin yah tindakan al-rishwah dan al-ghul $l$ tidak ada ketentuan yang tegas hukuman dunia dalam nash, dalam kitab-kitab fikih klasik ditentukan hukuman ta'z r. Hukuman ta'z $r$ ini diserahkan sepenuhnya oleh yang berwenang (hakim) melalui ijtihadnya berdasarkan perbuatan yang dilakukan dan dampaknya.

Konsep penghapusan pidana sebagaimana dalam pasal $12 \mathrm{C}$ Undang-Undang No. 31 Tahun 1999 jo. Undang-Undang No. 20 Tahun 2001 tentang Pemberantasan Tindak Pidana Korupsi dinyatakan bahwa jika penerima melaporkan gratifikasi yang diterimanya paling lambat 30 hari kerja kepada Komisi Pemberantasan Tindak Pidana Korupsi Penulis berpendapat para pejabat atau pegawai negeri bisa 
berlindung di balik Pasal 12 C Undang-Undang No. 20 tahun 2001 yang semata-mata melapor saja ke KPK, namun kelanjutan dari laporan semuanya tidak ada yang tahu apakah tetap berlanjut ke penyidikan ataukah berhenti karena sakit, pergi ke luar negeri atau alasan-alasan lainnya yang menyebabkan dihentikan untuk sementara proses penyelidikan dan penyidikan. Hal itulah mengapa perbuatan gratifikasi seringkali di lapangan sangat sulit utuk dideteksi, apalagi pihak penerima akan melapor ke KPK seketika itu.

Dalam fikih jin yah suatu unsur pidana dapat dihapuskan dengan empat unsur yaitu unsur paksaan, mabuk, gila dan masih dibawah umur, jadi tindak pidana gratifikasi seharusnya tidak dapat dihapuskan. Namun, melaporkan gratifikasi Komisi Pemberantasan tindak pidana Korupsi akan bermanfaat baik bagi dirinya ataupun orang lain atau masyarakat luas. Ketika penerima gratifikasi tidak melaporkan ke komisi tersebut, maka akan berdampak buruk bagi si penerima maupun orang lain. Dampak buruk bagi si penerima yaitu akan diproses hukum sesuai dengan ketentuan perUndang-Undangan dan tentunya tidak akan bermanfaat bagi dirinya. Lalu dampak buruk bagi pihak lain, yaitu berupa terampasnya hak-hak orang lain untuk berbuat sesuatu, karena sudah diberikan hadiah, maka orang lain harus tunduk kepada orang yang memberi hadiah tersebut dan hal ini sangat merugikan banyak pihak.

Dalam fikih ada penegasan, apabila status gratifikasi haram, dilaporkan atau tidak kepada negara, statusnya tetap haram. Ketentuan fikih ini agaknya berbeda dengan yang dinyatakan dalam UndangUndang No 20 Tahun 2001. Menurut Undang-Undang ini, setiap gratifikasi yang diperoleh pegawai negeri atau penyelenggara negara adalah suap, tetapi ketentuan yang sama tak berlaku jika penerima melaporkan gratifikasi itu ke KPK paling lambat 30 hari kerja terhitung sejak tanggal gratifikasi diterima. Ketentuan Undang-Undang ini tampaknya kalah tegas dibanding pemikiran fikih, sehingga dikhawatirkan justru terkesan melegalkan praktik suap dan hadiah yang diharamkan.

Dalam fikih terdapat metode yang dinamakan sadd al-dzar ah, yaitu upaya preventif agar tak terjadi sesuatu yang menimbulkan dampak negatif. Hukum Islam tidak hanya mengatur perilaku manusia yang sudah dilakukan, tetapi juga yang belum dilakukan. Hal ini sejalur 
dengan salah satu tujuan hukum Islam, yakni mewujudkan kemaslahatan dan menghindari kerusakan (mafsadah). Penekanannya pada "akibat dari perbuatan" tanpa harus melihat motif dan niat si pelaku. Jika akibat atau dampak yang terjadi dari suatu perbuatan adalah sesuatu yang dilarang atau mafsadah, perbuatan itu jelas harus dicegah. Artinya, jika suatu perbuatan yang belum dilakukan diduga keras akan menimbulkan kerusakan (mafsadah), dilaranglah hal-hal yang mengarahkan pada perbuatan itu.

Penekanannya pada "akibat dari perbuatan" tanpa harus melihat motif dan niat si pencegah. Artinya, jika suatu perbuatan yang belum dilakukan diduga menimbulkan dampak negatif. Hukum Islam tidak hanya mengatur perilaku manusia yang sudah dilakukan, tetapi juga yang belum dilakukan. Hal ini sejalur dengan salah satu tujuan hukum Islam, yakni mewujudkan aku. Jika akibat atau dampak yang terjadi dari suatu perbuatan adalah sesuatu yang dilarang atau perbuatan itu jelas harus deras akan menimbulkan kerusakan, dilaranglah hal-hal yang mengarahkan pada perbuatan itu.

\section{Simpulan}

Setelah penulis mengkaji, mengumpulkan, merumuskan dan menganalisis data-data penelitian, maka dapat penulis simpulkan sebagai berikut:

Penghapusan Pidana bagi pejabat negara penerima gratifikasi yang melaporkan diri kepada Komisi Pemberantasan Tindak Pidana Korupsi (KPK) pada Pasal 12 C UU 31/1999 jo. UU 20/2001 mengindikasikan adanya kelemahan dalam hukum pidana materiil, yaitu penghapusan sifat melawan hukum materiil berwujud prosedur administrasi ketika melapor di Komisi Pemberantasan Tindak Pidana Korupsi (KPK). Dalam fikih terdapat metode yang dinamakan sadd al-dzar ah, yaitu upaya preventif agar tak terjadi sesuatu yang menimbulkan dampak negatif. Hukum Islam tidak hanya mengatur perilaku manusia yang sudah dilakukan, tetapi juga yang belum dilakukan.

Persamaan hukum positif dan fikih jin yah pada gratifikasi kepada pejabat negara terletak pada hukumnya yakni kedua sumber hukum tersebut sama-sama melarang tindakan gratifikasi. Sedangkan perbedaannya terletak pada hukuman dan implikasi yang diberikan 
terhadap penerima gratifikasi pada waktu melaporkan maupun tidak melaporkannya kepada KPK.

\section{Daftar Rujukan}

Arief, Barda Nawawi. Kapita Selekta Pidana. Bandung: Citra Aditya Bakti, 2003.

Asmawi. Relevansi Teori Maslahat dengan UU Pemberantasan Korupsi. Jakarta: Pustaka Dunia, 2009.

Audah, Abd al-Qadir. al-Tashrî̀ al-Jinâî al-Islâmy. Mesir: Dar al-Fikr alAraby, tth.

Chaerudin, et al. Strategi Pencegahan dan Penegakan Hukum Tindak Pidana Korupsi. Bandung: Refika Aditama, 2008.

Chazawi, Adami. Pelajaran Pidana; Stelsel Pidana, Tindak Pidana, TeoriTeori Pemidanaan dan Batasan Berlakunya Hukuman Pidana. Cet. 2. Jakarta: PT. Raja Grafindo Persada, 2002.

-.------. Hukum Pidana Materil dan Formil Korupsi di Indonesia. Malang: Bayumedia Publishing, 2005.

Departemen Agama RI. Al-Qur'an Tajwid dan Terjemahannya. Bandung: Syaamil Cipta Media, 2006.

Hamzah, Andi. Pemberantasan Korupsi melalui Hukum Pidana Nasional dan Internasional. Jakarta: PT Raja Grafindo Persada, 2005.

Hanafi, Ahmad. Asas-Asas Hukum Pidana Islam. Jakarta: Bulan Bintang, 1990.

Hartanti, Evi. Tindak Pidana Korupsi. Jakarta: Sinar Grafika, 2005.

Kaffah, Ervyn Moh., dan Asyiq Amrulloh. Fiqh Korupsi: Amanah Vs Kekuasaan. NTB: Solidaritas Masyarakat Transparansi, 2003.

Komisi Pemberantasan Korupsi Republik Indonesia. Mengenali dan Memberantas Korupsi. Jakarta: KPK, 2010.

Marsum. Fiqih Jinayat (Hukum Pidana Islam). Yogyakarta: BAG. Penerbit FH UII, 1991.

Muslich, Ahmad Wardi. Pengantar dan Asas Hukum Pidana Islam Fikih Jinayat. Jakarta: Sinar Grafika, 2004.

Nurdjana. Korupsi dalam Praktik Bisnis: Pemberdayaan Penegakan Hukum Program Aksi dan Strategi Penanggulangan Masalah Korupsi. Jakarta: Gramedia Utama, 2005. 
Republik Indonesia. Kumpulan Undang-Undang Tindak Pidana Korupsi. Bandung: Citra Umbara, 2008.

Sianturi, S.R. Asas-Asas Hukum Pidana di Indonesia dan Penerapannya. Jakarta: PBK. Gunung Mulia, 1996.

Suharto. Hukum Pidana Materiil. Jakarta : Sinar Grafika, 2002.

Syaltut, Syeikh Mahmud. al-Islâm Aqîdah wa Sharîah. terj. Fachruddin HS. Jakarta: Bina Aksara, 1985.

Umbara, Citra. Kitab Undang-Undang Hukum Pidana. Bandung: Citra Umbara, 2009. 